\title{
The Effects of Roller Massage, Massage, and Ice Bath on Lactate Removal and Delayed Onset Muscle Soreness
}

\author{
Soetanto Hartono ${ }^{1}$, Achmad Widodo ${ }^{1}$, Himawan Wismanadi ${ }^{1}$ and Gulbuldin Hikmatyar ${ }^{1}$ \\ ${ }^{1}$ Surabaya State University, Faculty of Sport Sciences, Surabaya, Indonesia
}

\begin{abstract}
The purpose of the study was to investigate the effects of rolling massage, massage, and ice bath on lactate removal and delayed onset muscle soreness. Thirty students of Faculty of Sport Sciences of third semester were randomly selected and assigned to three groups, roller massage, massage, and ice bath group. All groups were doing Running-based Anaerobic Sprint Test (RAST) after 10 minute warm up. Eight minutes after RAST, all students were examined their blood lactate using blood lactate analyzer. The roller massage group was treated using foam roller for 5 minutes, , the massage group was massaged for 5 minutes, the ice bath group were put in 10 degree cold water for 5 minutes, then their blood lactate were reexamined. The normality test of roller massage is .022 , and homogeinity test $p=.133$, so the data was analized using nonparametric Kruskal Wallis. Contrary to results of other studies, lactate removal tends to be the most effective in ice bath treatment (17.40) compared with massage treatment (16.65), and roller massage (12.45), and reduction in Delayed Onset Muscle Soreness (DOMS) tends to be most effective in ice bath treatment (12.25) compared with massage treatment (13.95), and roller massage (20.30) eventhough non significant $(p=.399)$. Vasoconstriction effect of ice bath made a faster lactate removal, physique trait also might have an effect. Cooling effect of ice bath has an effective analgetic effect.
\end{abstract}

Key words: massage, roller massage, ice bath, blood lactate, Delayed Onset Muscle Soreness (DOMS)

\section{Introduction}

High intensity exercise could cause muscle injury and connective tissue damage. Injury and inflammation causes pain that manifests one to three days post anaerobic activity, known as delayed onset muscle soreness (DOMS) (Harlinda, 2014). Anaerobic work produces lactate, and accelerated lactate clearance as well as fast reduction of DOMS is needed to support sport performance in a series of anaerobic activities

Popular methods being used to get fast recovery are active recovery, massage, contrast hot and cold water treatment, ice bath, and recently roller massage. Ice bath is more effective within $10-15^{\circ} \mathrm{C}$ and $5-15$ minute duration (Versey, Halson, \& Dawson, 2013). Dupuy, Douzi, Theurot, Bosquet and Dugué (2018) analized systematically through meta-analysis about recovery technique to treat athletes after high intensive exercise and concluded that massage is the most effective methode to decrease inflammation, DOMS, and fatigue. Ingram, Dawson, Goodman, Wallman and Beilby (2009) proved that cold water immersion ia better than contrast water treatment in reducing DOMS and coming back to baseline during repeated sprint. There is not much proof that cold water immersion fascilitates lactate metabolism, but cold water immersion decreases muscle damage and increases parasympathetic nerve function (Ihsan, Watson, \& Abbiss, 2016).

The purpose of this study was to find out the effectiveness of massage versus cold water immersion in reducing lactate and DOMS after doing RAST in tropical region, and whether physique trait influences result.

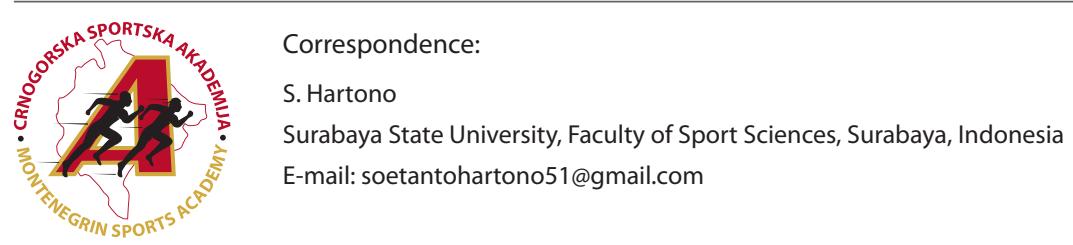




\section{Methods}

The design of this study was randomized pretest posttest group design. Thirty of second year students of Fakulty of Sport Science, Surabaya State University were randomly selected and randomly assigned to three groups consisted of 10 students, the roller masage group, the massage group, and the Ice Bath group. After 10 minute warming up, all three groups were doing Running-based Anaerobic Sprint Test (RAST). After RAST, all participants took 8 minute rest before blood sample was taken to determine their lactate level using lactate analyzer Accutrend, then the roller massage group was doing massage using foam roller for 5 minutes, the massage group was massaged for 5 minutes, and the Ice Bath group entered a container of $10^{\circ} \mathrm{C}$ cold water for 5 minutes. After that, all three groups were taken their blood samples for the second time to determine their lactate level after roller massage, massage, and Ice Bath treatments. Twenty four hours later, all participants reported the Delayed Onset Muscle Soreness (DOMS) according to their perception using 1 to 6 Scale.

This study was approved in advance by Ethical Board of the Surabaya State University with certificate number: 462 $\mathrm{IO} / 18$. Each participant voluntarily provided written informed consent before participating.

\section{Results}

Table 1 shows that In normality test, ice bath has $\mathrm{p}=.200$, massage $p=.200$ and roller $p=.022$. It means that sample is not normally distributed, so that non-parametric statistics shoul be used to analize the data

Table 1. Tests of Normality

\begin{tabular}{|c|c|c|c|c|c|c|c|}
\hline & \multirow{2}{*}{ method } & \multicolumn{3}{|c|}{ Kolmogorov-Smirnov ${ }^{a}$} & \multicolumn{3}{|c|}{ Shapiro-Wilk } \\
\hline & & Statistic & df & Sig. & Statistic & df & Sig. \\
\hline \multirow{3}{*}{$\begin{array}{c}\Delta \text { (pretest-posttest }) \\
\text { lactate }\end{array}$} & Ice Bath & .170 & 10 & $.200 *$ & .958 & 10 & .763 \\
\hline & Roller & .284 & 10 & $.022 *$ & .830 & 10 & .034 \\
\hline & Massage & .211 & 10 & $.200 *$ & .889 & 10 & .167 \\
\hline \multirow{3}{*}{$\begin{array}{l}\text { Posttest only } \\
\text { DOMS }\end{array}$} & Ice Bath & .329 & 10 & .003 & .655 & 10 & .000 \\
\hline & Roller & .329 & 10 & .003 & .655 & 10 & .000 \\
\hline & Massage & .302 & 10 & .010 & .781 & 10 & .008 \\
\hline
\end{tabular}

Legend: $\mathrm{df}$ - number of degreese of freedom, sig. - significance of two-tailed testing of arithmetic mean difference,

$\Delta$ - pretest-posttest, DOMS - delayed onset muscle soreness

Table 2 based on mean, homogeneity test shows $\mathrm{p}=.009, \quad$ rametric statistics should be used to analize the data. meaning that sample is not homogenous, and again non-pa-

Table 2. Test of Homogeneity of Variance

\begin{tabular}{llcccc}
\hline & & Levene Statistic & df1 & df2 & Sig. \\
\hline \multirow{4}{*}{$\begin{array}{llccc}\text { (pretest-posttest) } \\
\text { lactate }\end{array}$} & Based on Mean & 5.665 & 2 & 27 & .009 \\
& Based on Median & 1.881 & 2 & 27 & .172 \\
& Based on Median and with adjusted & 1.881 & 2 & 21.828 & .176 \\
& df & 5.237 & 2 & 27 & .012 \\
\cline { 2 - 6 } Posttest only & Based on trimmed mean & 1.969 & 2 & 27 & .159 \\
DOMS & Based on Mean & 1.703 & 2 & 27 & .201 \\
& Based on Median & 1.703 & 2 & 17.677 & .211 \\
\hline
\end{tabular}

Legend: df1 - number of degree of freedom 1, df2 - number of degree of freedom 2, sig. - significance of two-tailed testing of arithmetic mean difference, $\Delta$ - pretest-posttest, DOMS - delayed onset muscle soreness

Table 3 Kruskall-Wallis test shows that the highest lactate removal is given by Ice Bath (17.40) followed by Massage (16.65) and Roller massage (12.45). It means the most effective way to reduce lactate is Ice Bath, eventhough it is not signifi- cant (asymtotic $\mathrm{p}=.399)$. The lowest perception of muscle soreness happens after sample treated by Ice Bath (12.25), followed by massage (13.95) and roller massage (20.30) eventhough statistically non significant

Table 3. Kruskal-Wallis

\begin{tabular}{cccc}
\hline Method & Method & N & Mean Rank \\
\hline \multirow{3}{*}{$\Delta$ (petest-posttest) Lactate } & Ice Bath & 10 & 17.40 \\
& Roller & 10 & 12.45 \\
& Massage & 10 & 16.65 \\
& Total & 30 & \\
\cline { 2 - 4 } Posttest only DOMS & Ice Bath & 10 & 12.25 \\
& Roller & 10 & 20.30 \\
& Massage & 10 & 13.95 \\
\hline
\end{tabular}

Legend: $\mathrm{N}$ - number of cases, $\Delta$ - pretest-posttest, DOMS - delayed onset muscle soreness 
Table 4 shows that 2 tailed statistics are non-significant ( $\mathrm{p}$ lactate $=.734, \mathrm{p}$ DOMS $=.675$ ), so the results of this study can not be inferred to population.

Table 4. Test Statistics

\begin{tabular}{lcc}
\hline & $\Delta$ lactate & DOMS \\
\hline Mann-Whitney U & 45.500 & 45.000 \\
Wilcoxon W & 100.500 & 100.000 \\
Z & -.340 & -.419 \\
Asymp. Sig. (2-tailed) & .734 & .675 \\
Exact Sig. [2*(1-tailed Sig.)] & $.739^{\mathrm{b}}$ & $.739^{\mathrm{b}}$ \\
\hline
\end{tabular}

Legend: $\Delta$ - pretest-posttest, DOMS - delayed onset muscle soreness, asymp. Sig significance of two-tailed testing of arithmetic mean difference

\section{Discussion}

High intensity exercise causes muscle damage, oedema, hyperthermia, dehydration and used up glycogen reserve (Ihsan et al., 2016). The benefit of massage locally is to decrease pain, peripheral vasodilation, increase vein and lymphatic drainage, and activate local metabolism. Mechanical energy could stimulate new cappilary development (Shirinsky et al., 1989), mechanical signal could increase fibroblast proliferation, which is important to stimulate recovery in injury area (Curtis \& Seehar, 1978). Jain, Berg and Tandon (1990) showed that mechanical stimulation on fibroblast cause cell development, protein synthesis and increased intercellular cyclic adenosine monophosphate (cAMP) 24 hours after stimulation. Mechanical stimulation will activate fibroblast and collagen synthesis and extracellular matrix in injury area. Fibroblast activation followed by collagen synthesis is an important in recover process almost in any tissue (Jain et al., 1990). In a controlled study, Butterfield, Zhao, Agarwal, Haq and Best (2008) found that 30 minute massage on rabbit anterior tibialis which was doing eccentric contraction would decrease tissue necrosis compared with those not being massaged. Butterfield et al. (2008) showed that massage was efective in decreasing cell infitration, inflammation or oedema so as to fascilitate recovery process. Waters-Banker, Dupont-Versteegden, Kitzman and Butterfield (2014) added that massage could have an immunomodulatory therapeutic modality, it makes changes through immunity response. Through tranduction mechanism, massage was able to change the phenotype of macrophage M1 which has proinflammatory character to macrophage M2 which has anti- inflammatory character through differentiation of T helper cell Th1 to become Th2. Th2 cells instead can promote macrophage differentiation, creating an abundance of M2 anti-inflammatory phenotype and signifying the repair and regeneration phase. Cell or tissue damage will increase along with intensity and exercise duration since the cell will continuously send mechanical signal that become chemical response (Butterfield, 2010). Timing of the massage treatment will influence its immunomodularry effects. Massage would be more effective if given immediately after injury (Waters-Banker et al., 2014).

Pain inhibition involves endogenous morphine, as opioid receptors like $\mu$ and $\kappa$ receptors in Peri Aquaductal Grey matter are activated (Mansour, Fox, Akil, \& Watson, 1995). Oxytocinergic mechanism is also activated (Uvnas-Moberg, Bruzeliu, Alster, \& Lundeberg, 1993). Strong massage pressure will stimulate a faster recovery than light or moderate pressure (Gehlsen, Ganion \& Helllfst, 1999).

There are some theories of Delayed Onset Muscle Soreness (DOMS), namely; lactic acid, muscle spasm, connective tissue damage, muscle damage, and inflammation. Integration of these theories is likely to explain DOMS (Cheung, Hume, \& Maxwell, 2003). The primary cause of DOMS is eccentric contraction that makes micro injury with the most serious condition. Several strategies to recover from DOMS or to reduce the seriousness of DOMS are massage, stretching, anti inflammatory drugs or cryo therapy. Fridén, Sfakianos and Hargens (1986) concluded that if muscle was used for unusual activities, there was disturbance on myofibril and cell structural framework followed by increased lysosome activity.

Some studies explain that cold water immersion can make faster recovery, but it is considered that the most effective one is cold water immersion with temperature $10-15^{\circ} \mathrm{C}$ in $5-15 \mathrm{minu}-$ tes (Versey et al., 2013). Many studies indicate that cold water immersion fascilitates recovery by decreasing hyperthermia and fatigue, there is not much proof that cold water immersion fascilitates lactate metabolism, but cold water immersion decreases muscle damage and increases parasympathetic nerve function (Ihsan et al., 2016).

Physiological changes during cold water immersion that increases recovery time include intracellular-intravascular fluid shift, reduction in muscle edema and fatigue, increased blood flow with possible nutrient and waste transportation (Wilcock, Cronin, \& Hing, 2006). Differences in physique traits, depth of the water, duration of the immersion and temperature, kinds of exercise, will influence the results (Stephens, Halson, Miller, Slater, \& Askew, 2017). Dupuy et al. (2018) analized systematically through meta-analysis about recovery technique to treat athletes after high intensive exercise and concluded that massage is the most effective methode to decrease inflammation, DOMS and fatigue. Ingram et al. (2009) proved that cold water immersion ia better than contrast water treatment in reducing DOMS and coming back to baseline during repeated sprint.

Contrary to studies conluded by Ihsan et al. (2016) and Dupuy et al. (2018), this study conducted in School of Sport Sciences, Surabaya State University proves that cold water immersion (CWI) $10^{\circ} \mathrm{C}$ for 5 minutes after doing Running-based Anaerobic Sprint Test causes lactate as well as DOMS reduction better than massage treatment. Lactate reduction through CWI vs massage (10.95 vs $10.05, \mathrm{p}=.739$ ) and DOMS reduction is greater in ice bath treatment than massage (10 vs 11 ), eventhough they are not significant $(\mathrm{p}=.739)$. This is contrary to what was concluded by Ihsan et al. (2016) saying that there was not enough evidence that ice bath treatment fascilitated lactate metabolism, and also conclusion made Dupuy et al. (2018) saying that massage was the best recovery technique from fatigue and DOMS. Physique trait of people living in tropical area might cause greater vasoconstriction then people living with 
four seasons and removed lactate faster. Physique trait could make difference in reaction to cold, and might make cold water immersion more effective than massage in reducing lactate and DOMS. Obviously, Ice Bath is a very effective treatment of any anaerobic activity, especially if eccentric contraction is involved.

\section{Acknowledgements}

There are no acknowledgements.

\section{Conflict of Interest}

The authors declare that there are no conflicts of interest.

Received: 22 February 2019 | Accepted: 07 April 2019 | Published: 01 June 2019

\section{References}

Butterfield, T.A., Best, T.M., \& Merrick, M.A. (2006). The dual roles of neutrophils and macrophages in inflammation: a critical balance between tissue damage and repair. J Ath/ Train, 41(4), 457-465.

Butterfield, T.A., Zhao, Y., Agarwal, S., Haq, F., \& Best, T.M. (2008). Cyclic compressive loading facilitates recovery after eccentric exercise. Med Sci Sports Exerc 40(7), 1289-1296.

Butterfield, T.A. (2010). Eccentric exercise in vivo: strain-induced muscle damage and adaptation in a stable system. Exerc Sport Sci Rev, 38(2), 51-60.

Cheung, K., Hume, P.A., \& Maxwell, L. (2003). Delayed Onset Muscle Soreness. Treatment Strategies and Performance Factors. Sports Medicine. Volume, 33, $145-164$.

Curtis, A.S.G., \& Sheehar, G.M. (1978). The Control of Cell Division by Tension or Diffusion; Nature, 274, 52-53.

Draper, N. \& Whyte, G. (1997). Here's a new running based test of anaerobic performance for which you need only a stopwatch and a calculator. Peak Performance, 96, 3-5.

Dupuy, O., Douzi, W., Theurot, D., Bosquet, L., \& Dugué, B. (2018). An Evidence-Based Approach for Choosing Post-exercise Recovery Techniques to Reduce Markers of Muscle Damage, Soreness, Fatigue, and Inflammation: A Systematic Review with Meta-Analysis. Front Physiol, 26, 9-403.

Fridén, J., Sfakianos, P.N., \& Hargens. A.R. (1986). Muscle soreness and intramuscular fluid pressure: comparison between eccentric and concentric load. $J$ Appl Physiol, 61(6), 2175-9.
Gehlsen, G.M., Ganion, L.R., \& Helllfst, R. (1999). Fibroblast Responses to Variation in Soft Tissue Mobilization Pressure. Med. Sci. Sports Med, 31(4), 531-535.

Harlinda. (2014). Delayed Onset Muscle soreness. Jakarta:LPP FKUI.

Ihsan, M., Watson, G., Abbiss, C.R. (2016). What are the Physiological Mechanisms for Post-Exercise Cold Water Immersion in the Recovery from Prolonged Endurance and Intermittent Exercise? Sports Med., 46(8), 1095-109.

Ingram, J., Dawson, B., Goodman, C., Wallman, K., \& Beilby, J. (2009). Effect of water immersion methods on post-exercise recovery from simulated team sport exercise. J Sci Med Sport, 12(3), 417-21.

Jain, M.K., Berg, R-A., \& Tandon, G.P. (1990). Mechanical Stress and Cellular Metabolism in Living Soft Tissue Composites. Biomaterials, 34, 465471

Mansour, A., Fox, C.A., Akil, H., \& Watson, S.J. (1995). Opioid receptor mRNA expression in the rat CNS: anatomical and functional implication. Trends Neurosci, 18, 22-29.

Sellwood, K.L., Brukner, P., Williams, D., Nicol, A., \& Hinman, R. (2007) Ice-water immersion and delayed-onset muscle soreness: a randomised controlled trial.B r J Sports Med, 41, 392-7.

Shirinsky, V.P., Antonov, A.S., Birukov, K.G., Sobolevsky, A.V., Romanov, Y.A., Kabaeva, N.V., Antonova, G.N., \& Smirnov, V.N. (1989). Mechano-Chemical Control of Human Endothelium Orientation and Size. J. Cell Biol., 109, 331-339.

Sofroniev, M.V. (1983). Vasopresin and Oxytosin in the mammalian brain and spinal cord. Trends Neurosci, 6,167-172.

Stephens, J.M., Halson, S., Miller, J., Slater, G.J., \& Askew, C.D. (2017). Cold-Water Immersion for Athletic Recovery: One Size Does Not Fit All. Int J Sports Physiol Perform, 12(1), 2-9.

Uvnas-Moberg, K., Bruzeliu, G., Alster, P., \& Lundeberg, T. (1993). The antinociceptive effect of non-noxious sensory stimulation is mediated partly through oxytocinergic mechanism. Acta Physiol Scand, 149, 199-204.

Versey, N.G., Halson, S.L., \& Dawson, B.T. (2013). Water immersion recovery for athletes: effect on exercise performance and practical recommendations. Sports Med, 43(11), 1101-30.

Wilcock, I.M., Cronin, J.B., \& Hing, W.A. (2006). Physiological response to water immersion: a method for sport recovery? Sports Med, 36(9), 74765.

Waters-Banker, C., Dupont-Versteegden, E.E., Kitzman, P.H., \& Butterfield T.A. (2014). Investigating the Mechanisms of Massage Efficacy: The Role of Mechanical Immunomodulation. J Athl Train, 49(2), 266-273. 